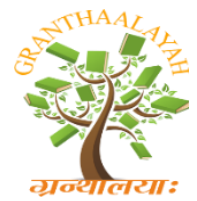

\author{
INTERNATIONAL JOURNAL OF RESEARCH - \\ GRANTHAALAYAH \\ A knowledge Repository
}

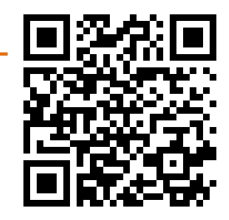

Science

\title{
IN VIVO ANTIDIABETIC ACTIVITY AND MECHANISM OF ACTION OF THREE CAMEROONIAN MEDICINAL PLANT EXTRACTS
}

\section{Larissa Chimi Yetendje ${ }^{1}$, Guy Sedar Singor Njateng1, *2, Armel-Joseph Agokeng Dongmo ${ }^{1}$, Raymond Simplice Mouokeu ${ }^{3}$, Cesaire Feudjio ${ }^{1}$, Stephen Lacmata Tamekou ${ }^{1}$, Jamshed Iqbal $^{2}$}

${ }^{1}$ Faculty of Sciences, University of Dschang, P.O. Box 67, Dschang, Cameroon

${ }^{2}$ Center for Advance Drug Research, COMSATS Institute of Information Technology, Abbottabad-22060, Pakistan

${ }^{3}$ Institute of Fisheries and Aquatic Sciences, University of Douala, P.O. Box 7236, Douala, Cameroon

\begin{abstract}
The aim of the present work is to study and compare antidiabetic activity of extracts from Catharentus roseus, Persea americana, and Eucalyptus globulus as well as their mechanism of action. The aqueous and methanolic plant extracts were respectively prepared by decoction and maceration. The phytochemical screening was done by standard methods. The extracts were subsequently tested in vivo on Wistar albino rats (Rattus norvegicus) with temporary hyperglycemia. The methanolic extract of $P$. americana leaves showing the best activity was selected for the antidiabetic test at doses 37.5, 75 and $150 \mathrm{mg} / \mathrm{kg}$. For that purpose, permanent diabetes mellitus was induced in rats fasted overnight by intraperitoneal injection of alloxan (150 $\mathrm{mg} / \mathrm{kg}$ ). Hematological and biochemical parameters were evaluated from the cardiac puncture's blood. The antidiabetic mechanism of action of the 6 extracts was performed by evaluating their inhibitory activity on alpha glucosidase, beta glucosidase and glucoamylase.

Phytochemical analysis of aqueous and methanolic extracts revealed that all extracts contain phenols, anthraquinones and tannins. On the other hand, no extract contains sterols. All extracts showed hypoglycemic activities. The antidiabetic tests showed that the methanolic extract of $P$. americana caused a decrease in blood sugar level in all the treated rats with the dose of $150 \mathrm{mg} /$ $\mathrm{kg}$ of body weight being the most effective, without any adverse side effect in the animals. All the tested extracts showed an inhibitory activity against alpha glucosidase and glucoamylase enzymes and have no inhibitory activity on beta glucosidase.

The results of the present study demonstrate the antidiabetic properties of the tested plants through inhibitory effect on alpha glucosidase and glucoamylase enzymes with $P$. americana being the most active.
\end{abstract}

Keywords: Diabetes; C. Roseus; P. Americana; E. Globulus; Mechanism of Action.

Cite This Article: Larissa Chimi Yetendje, Guy Sedar Singor Njateng, Armel-Joseph Agokeng Dongmo, Raymond Simplice Mouokeu, Cesaire Feudjio, Stephen Lacmata Tamekou, and 
Jamshed Iqbal. (2019). "IN VIVO ANTIDIABETIC ACTIVITY AND MECHANISM OF ACTION OF THREE CAMEROONIAN MEDICINAL PLANT EXTRACTS.” International Journal of Research - Granthaalayah, 7(8), 415-430. 10.29121/granthaalayah.v7.i8.2019.695.

\section{Introduction}

Diabetes mellitus is a group of metabolic diseases characterized by chronic hyperglycemia [1]. Epidemological data are upgrading and alarming: 442 million people with diabetes were diagnosed worldwide in 2014, and 516 thousand in Cameroon by the International Diabetes Federation [2]. According to projections, an increase of $54 \%$ in the world and $80 \%$ in Cameroon is expected by 2035 [2]. Seventy-five percent (75\%) of these deaths occurred in people under 60 years of age with a high rate among young people aged 20 to 39 [2].

There are numerous antidiabetic treatments, namely oral antidiabetic drugs such as acarbose, glibenclamide, metformin, and insulin. However, these drugs are expensive, unavailable and cause many adverse side effects [3]. Hence, the need to find new substances with antidiabetic properties. Medicinal plants that have the advantage of being available, with little or no toxicity, could be a good source for such substances. Feudjo et al. conducted an ethnobotanical survey in three villages (Njisse, Njimbam I and Njimbam II) of the Foumban district after what he found that among the most represented species used alone in the treatment of diabetes, are Catharenthus roseus, Eucalyptus globulus, and Persea americana [4] with decoction being the mode of preparation used by the healers. Al-Shaqha et al. observed the antidiabetic effect of ethanolic extract from C. roseus on diabetic wistar rats and greatly advocate its candidature for the design of a novel herbal drug to cure deadly diabetes [5]. Comparative study undertaken to determine the hypoglycemic effect of 96\% ethanolic extracts of Eucalyptus globulus, Salvia officinalis and Guiera senegalensis leaves demonstrated that the Eucalyptus globulus extract had a significant blood-glucose lowering potential in glucose loaded rats [6]. The hypoglycaemic and tissue-protective effects of hot aqueous Persea americana (avocado pear) seed extract on alloxan-induced albino rats were investigated and findings provided a pharmacological basis for the folkloric use of that extract in the management of diabetes mellitus [7]. Furthermore, Njateng et al. in an in vitro study, showed that methanol extract from leaves of $P$. americana Mill strongly inhibits alpha-glucosidase, maltase-glucoamylase, aldose reductase and aldehyde reductase and showed almost no effect against beta-glucosidase [8]. As a continuity of this study, our work aimed at evaluating in a comparative way the in vivo antidiabetic activity of aqueous and methanol extracts from these plants using rat as animal model, as well as their mechanisms of action because, to the best of our knowledge, this has not yet been done.

\section{Methods}

\subsection{Plant Materials}

The medicinal plants used in this study were $C$. roseus .L. (leaves), P. americana L. (leaves), E. globulus L. (leaves), collected in the Ndé Division (West Region of Cameroon) in February 2017. These plants were identified and authenticated at the Cameroon National Herbarium in comparison to the registered specimens under reference 43386/HNC, 57756/HNC and 477/SRFCM 
respectively. The leaves of each plant were washed thoroughly using distilled water and dried under room temperature. They were ground to powder and stored in air tight bottles.

\subsection{Preparation of Crude Extracts}

The air-dried and powdered sample from each plant was submitted to two extraction processes. $200 \mathrm{~g}$ of plant powder were macerated in $600 \mathrm{ml}$ of methanol for $48 \mathrm{~h}$ at room temperature with constant shaking. After $48 \mathrm{~h}$, the extract was filtered through a Whatman $\mathrm{N}^{\mathrm{o}} 1$ filter paper. The filtrate was then evaporated to dryness at $45^{\circ} \mathrm{C}$ for methanol using a rotary evaporator to give a residue which constituted the methanol crude extract. The extraction yield was calculated (Table 1) and the crude extract was kept at $+4^{\circ} \mathrm{C}$ until further use. The aqueous extraction was carried out by decoction of $200 \mathrm{~g}$ of powder in $600 \mathrm{ml}$ of sterile distilled water for 15 minutes. After cooling, the mixture was filtered and the obtained filtrate was dried in an oven.

\subsection{Phytochemical Screening of Extracts}

Phytochemical screening of the extracts was performed according to the standard method [9]. The plant extract was screened for the presence of different classes of compounds including alkaloids, flavonoids, steroids, triterpenes, anthraquinones, tannins, anthocyanins, saponins and polyphenols.

\subsection{Experimental Animals}

Fifty one Wistar albino rats (Rattus norvegicus) aged 3 to 4 months and weighing between 150$200 \mathrm{~g}$ were used. They were obtained and bred in the animal house of the Department of Biochemistry, University of Dschang, Cameroon. The rats were acclimatized for two weeks to laboratory conditions $\left(22 \pm 2^{\circ} \mathrm{C}\right)$ and were given food and water ad libitum. Animals were randomly selected, caged individually and randomly assigned to control and test groups.

All studies involving animals were conducted according to the ethical guidelines of the Committee for Control and Supervision of Experiments on Animals (Registration no. 173/CPCSEA, dated 28 January, 2000), Government of India, on the use of animals for scientific research.

\subsection{Antidiabetic Assay}

\subsubsection{Determination of The Glycaemia}

Glycaemia was measured based on a single drop of blood obtained from the caudal end of the animals after excision (venous blood) using a glucometer with reactive strips (Accu Check Active) Rock manufactured in April 2016 and of batch number 24649031. This drop of blood was deposited on the active zone of a strip followed by automatic reading of the glycaemia 5 seconds later. The result was expressed in $\mathrm{mg} / \mathrm{dL}$ of blood [4].

\subsubsection{Preliminary tests in rats with temporary hyperglycemia}

Two groups made up of 3 lots of 3 rats each were constituted in addition to the three control groups (Healthy, negative and positive controls). Rats were force-fed with a $60 \%$ glucose solution at 4 
$\mathrm{g} / \mathrm{kg}$ body weight dose, using a gastroesophageal tube [4]. Aqueous extracts $(37.5 \mathrm{mg} / \mathrm{kg}$ body weight) were used in the first group while methanol extracts $(37.5 \mathrm{mg} / \mathrm{kg}$ body weight $)$ were used in the second group. Healthy control animals were not force-fed with $60 \%$ glucose while negative control animals were. Both groups didn't receive treatment. Positive control rats were force-fed with $60 \%$ glucose and treated with glibenclamide at a dose of $2.5 \mathrm{mg} / \mathrm{kg}$ body weight.

At time $\mathrm{t}=0$ minutes, (30 min before administration of the glucose overload), and every 30 minutes for three hours the glucose level was determined. At the end of this test the most active extract was selected for the study of the antidiabetic activity.

\subsubsection{Induction of Diabetes in Rats}

Permanent diabetes mellitus was induced in rats fasted overnight by intraperitoneal injection of alloxan monohydrate $(150 \mathrm{mg} / \mathrm{kg})$ [10]. The aqueous solution of alloxan was prepared just before injection. After injection of the alloxan solution, the rats were returned to the cages and systematically had free access to the diet and a 5\% glucose solution overnight to avoid hypoglycaemic shock. Seventy-two hours after injection of alloxan, the establishment of diabetes mellitus was verified in rats by measuring blood glucose level. Animals with blood glucose level greater than $333 \mathrm{mg} / \mathrm{L}$ were in permanent hyperglycaemia [4] and were selected for the study.

\subsubsection{Effect of Crude Extracts of P. Americana in Diabetic Rats}

Rats were randomly distributed into six groups of three animals each and treated by force-feeding for 28 days. Group 1 or healthy control animals (HC), were not suffering from diabetes; group 2 or negative control animals were diabetic rats without treatment; group 3 or positive control were diabetic rats treated with glibenclamide at a dose of $2.5 \mathrm{mg} / \mathrm{kg}$; groups 4,5 and 6 animals were treated with the extract of $P$. americana at the dose D1 $=37.5 \mathrm{mg} / \mathrm{kg}, \mathrm{D} 2=75 \mathrm{mg} / \mathrm{kg}$, and D3 = $150 \mathrm{mg} / \mathrm{kg}$ respectively.

Blood glucose levels were measured daily during the first week of treatment and once a week for 3 weeks.

\subsubsection{Determination of Hematological and Biochemical Parameters}

\section{Sample Collection}

On the 28th day of experiment, the animals were subjected to overnight fasting and left in their individual metabolic cages. Blood samples were collected by cardiac puncture from anaesthetized and unconscious rats following intraperitoneal injection of thiopental $(0.2 \mathrm{~mL} / 100 \mathrm{~g})$ and introduced into EDTA and non EDTA tubes. The blood contained in EDTA tubes was used for the determination of hematological parameters while the blood in tubes without EDTA was allowed to clot 3 hours in ice and then centrifuged at $3000 \mathrm{~g}$ for 20 minutes. The obtained serum was transferred into labeled eppendorf tubes and stored at $-30{ }^{\circ} \mathrm{C}$ until the biochemical parameters were determined [4]. The anaesthetized unconscious animals were sacrificed by laparotomy for gross pathological examinations, collection and weighing of different organs (liver, kidney, lung, heart and spleen) [11]. 


\section{Biochemical Assay}

Serum parameters such as total cholesterol, total triglycerides, creatinine, urea, total proteins and enzymes such as alanine aminotransferase (ALT) and aspartate aminotransferase (AST), were measured using commercial kits. The assays were colorimetrically monitored and the absorbance readings were made using a Genesys brand spectrophotometer.

\subsubsection{Determination of The Antidiabetic Mechanism of Action of Extracts}

The determination of the antidiabetic mechanism of action of extracts was performed by evaluating the activity of the extracts against alpha glucosidase, beta glucosidase and glucoamylase.

For the determination of inhibition percentages, all the extracts were tested at $0.1 \mathrm{mg} / \mathrm{ml}$, with the exception of the methanol extract of $P$. americana and E. globulus as well as the aqueous extract of E. globulus that were tested at $0.05 \mathrm{mg} / \mathrm{mL}$ (because at $1 \mathrm{mg} / \mathrm{mL}$ these extracts were highly concentrated to have an activity between 0 and 100\%). In contrast, for $\mathrm{IC}_{50}$ determination, all extracts were tested at concentrations of $0.1,0.03,0.01,0.003,0.001,0.0003,0.0001$ and 0.00003 $\mathrm{mg} / \mathrm{mL}$. Acarbose was used as a standard for $\alpha$-glucosidase and glucoamylase, whereas castanospermine was used as standard for $\beta$-glucosidase [8].

\section{Alpha Glucosidase and Glucoamylase Inhibition Test}

The $\alpha$-glucosidase and glucoamylase inhibition test was performed using the protocol described by Ma et al. [12]. Solutions of $\alpha$-glucosidase (Saccharomyces cerevisiae), glucoamylase and their substrate (p-nitrophenyl- $\alpha$-Dglucopyranoside (pNPG) were prepared in phosphate buffer (70 mM, $\mathrm{pH}$ 6.8). Dimethyl sulphoxide was used as a surfactant for the preparation of the extract solutions. The inhibition tests were carried out by adding $10 \mu \mathrm{L}$ of extract solution to $70 \mu \mathrm{L}$ of buffer and 10 $\mu \mathrm{L}$ of enzymatic solution (2.5 units / $\mathrm{mL})$ in phosphate buffer $(70 \mathrm{mM}, \mathrm{pH} 6.8)$ followed by preincubation at $37{ }^{\circ} \mathrm{C}$ for 5 minutes. After preincubation, $10 \mu \mathrm{L}$ of $10 \mathrm{mM}$ substrate (pNPG) prepared in phosphate buffer was added to the mixture to initiate the enzymatic reaction. The reaction mixture was incubated at $37^{\circ} \mathrm{C}$ for $30 \mathrm{~min}$, and the reaction stopped by the addition of 80 $\mu \mathrm{L}$ of $\mathrm{Na}_{2} \mathrm{CO}_{3}(0.2 \mathrm{M})$. Acarbose was used as positive control. $\alpha$-glucosidase activity was determined by measuring p-nitrophenol released from pNPG at $405 \mathrm{~nm}$ using an Elx 800 Micro Plate Reader. For each test, three repetitions were performed. Percent inhibition was calculated using the following equation:

Inhibition $(\%)=[100-($ A sample/A control $)] \mathrm{X} 100 \mathrm{~A}=$ Absorbance or optical density

\section{Inhibition Test of $\beta$-Glucosidase}

To determine the inhibitory effect against $\beta$-glucosidase activity, the test was performed based on previously published method [8]. B-glucosidase (from sweet almonds) and p-nitrophenyl- $\beta$-Dglucopyranoside (pNPG) as substrate were prepared in $0.07 \mathrm{M}$ phosphate buffer ( $\mathrm{pH}$ 6.8). The inhibition tests were carried out by adding an extract solution $(10 \mu \mathrm{l})$ to $70 \mu \mathrm{l}$ of buffer and $10 \mu \mathrm{l}$ of enzymatic solution (2.0 units $/ \mathrm{ml}$ ) in a $0.07 \mathrm{M}$ phosphate buffer $(\mathrm{pH} 6,8)$ followed by preincubation at $37{ }^{\circ} \mathrm{C}$ for $5 \mathrm{~min}$. After preincubation, $10 \mu \mathrm{l}$ of $10 \mathrm{mM}$ p-nitrophenyl glucopyranoside (pNPG) as substrate in phosphate buffer was added to the mixture to start the reaction. The reaction mixture was then incubated at $37^{\circ} \mathrm{C}$ for 30 minutes and quenched by adding 
$80 \mu \mathrm{L}$ of $\mathrm{Na} 2 \mathrm{CO} 3(0.2 \mathrm{M})$. The negative control contained $10 \mu \mathrm{L}$ of distilled water instead of an inhibitor. Castanospermine was used as positive control. For each test, three repetitions were made.

\subsection{Statistical Analysis}

The data from the daily blood glucose measurement as well as the various hematological and biochemical parameters were recorded in Microsoft Office Excel 2007 software. The values of the parameters were expressed in the form of mean \pm standard error of mean. After analysis of variance, the comparison of averages between different groups of rats was performed using Waller-Duncan test of SPSS software version 20.0. Enzymatic activity in the presence of extracts was expressed as a percentage of uninhibited enzyme activity and plotted against inhibitor concentration. Non-linear regression was performed using a four-parameter logistic model and GraphPad Prism software (GraphPad Software, La Jolla, CA).

\section{Results}

\subsection{Extraction Yield}

The extraction yield of the extracts is shown in Table 1 below. From this table, it appears that the extraction with methanol has a high yield compared to the aqueous extraction. The methanol extracts of $C$. roseus $(25.08 \%)$ and $P$. americana $(6.88 \%)$ showed the best and the lowest yield respectively.

Table 1: Extraction yield

\begin{tabular}{|l|l|c|c|c|}
\hline Plant & Extract type & Weight of the powder (g) & Weight of the extract (g) & Yield (\%) \\
\hline \multirow{2}{*}{ P. americana } & Methanol extract & 200 & 34.74 & 17.37 \\
\cline { 2 - 5 } & Aqueous extract & 200 & 13.76 & 6.88 \\
\hline \multirow{2}{*}{ C. roseus } & Methanol extract & 200 & 50.17 & 2508 \\
\cline { 2 - 5 } & Aqueous extract & 200 & 19.48 & 9.74 \\
\hline \multirow{2}{*}{ E. globulus } & Methanol extract & 200 & 35.37 & 17.68 \\
\cline { 2 - 5 } & Aqueous extract & 200 & 31.86 & 15.93 \\
\hline
\end{tabular}

\subsection{Phytochemical Screening}

Crude plant extracts were subjected to a phytochemical screening for the identification of the main groups of secondary metabolites. The results obtained are shown in Table 2. These latter reveal differences in chemical composition between extracts. But in general, all extracts contain phenols, anthraquinones and tannins. Except for the methanol extract of E globulus, all the other tested extracts contain alkaloids and flavonoids. On the other hand, no extract contains sterols.

Table 2: Phytochemical composition of plant extracts

\begin{tabular}{|l|l|l|l|l|l|l|l|l|l|l|}
\hline Plant & Extract & Fla & Alka & Trit & Phen & Sap & Tan & Anthra & Antho & Ster \\
\hline \multirow{3}{*}{ P. americana } & Methanol extract & + & + & - & + & + & + & + & + & - \\
\cline { 2 - 11 } & Aqueous extract & + & + & + & + & + & + & + & - & - \\
\hline \multirow{3}{*}{ C. roseus } & Methanol extract & + & + & + & + & - & + & + & - & - \\
\cline { 2 - 11 } & Aqueous extract & + & + & + & + & - & + & + & - & - \\
\hline \multirow{2}{*}{ E. globulus } & Methanol extract & - & - & - & + & + & + & + & - & - \\
\cline { 2 - 10 } & Aqueous extract & + & + & + & + & - & + & + & - & - \\
\hline
\end{tabular}




\subsection{Anti-Diabetic Test}

\subsubsection{Effect of Plant Extracts on Rats in Temporary Hyper-Glycemia}

In order to select the most active extract among the 8 tested extracts, a preliminary test was performed on rats with temporary hyperglycemia. The variation in glycemia in rats with temporary hyperglycemia pre-treated with plant extracts is presented in Figure 1 below. From this figure, there is a significant increase in glycemia 30 minutes after administration of glucose in treated and negative control rats. After 90 minutes, there was a decrease in blood glucose, this decrease being more pronounced in the rats treated with glibenclamide (at a dose of $2.5 \mathrm{mg} / \mathrm{kg}$ of body weight), moderately accentuated in rats treated with methanol extracts and little accentuated in rats treated with aqueous extracts. We observed that extracts resulting from extraction with methanol showed the best activities with the most active being the $P$. americana extract. This causes a decrease in blood sugar, reaching after 150 minutes' blood glucose equivalent to that of healthy control animals.

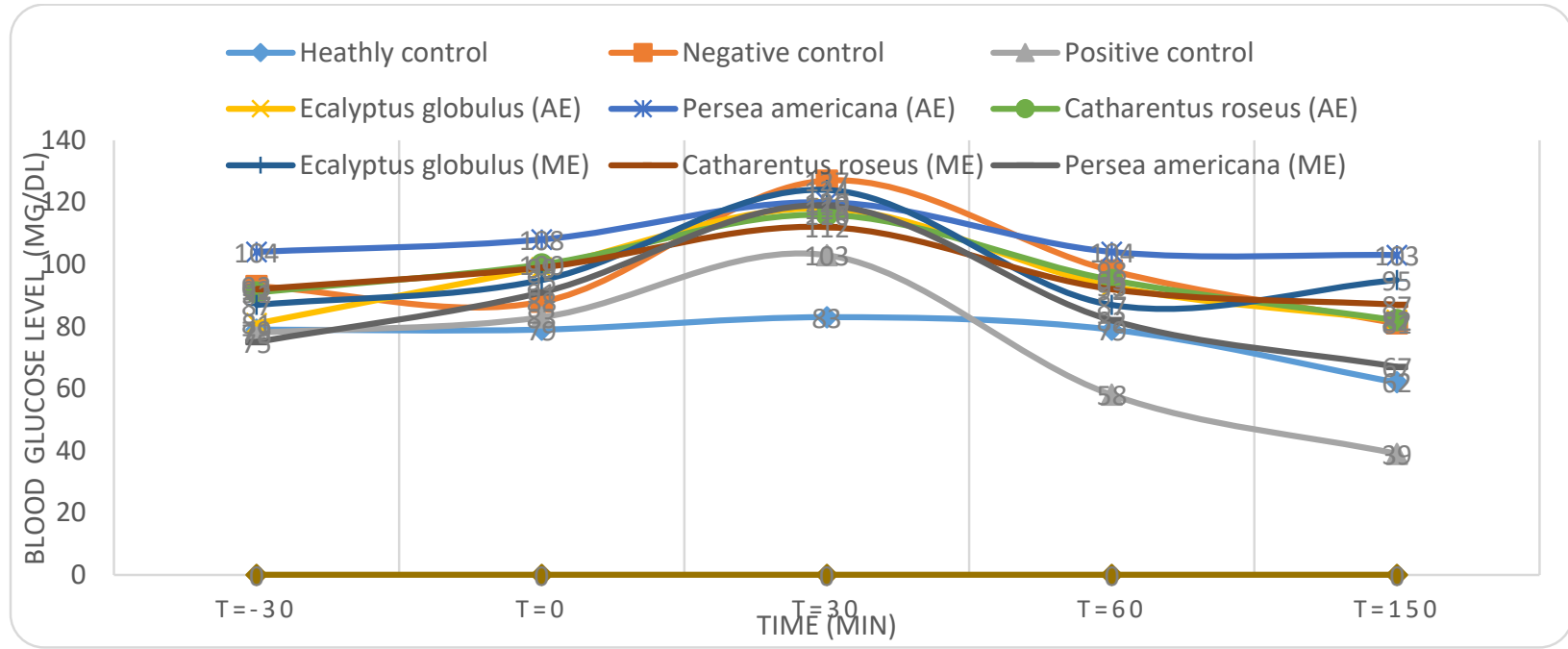

C: Control, AE: Aqueous Extract, ME: Methanol Extract

Figure 1: Variation of blood glucose levels in rats with temporary hyperglycemia pre-treated with plant extracts

\subsubsection{Effects of Methanol Extract of P. Americana on Diabetic Rats}

The anti-diabetic test was performed with the methanol extract of $P$. americana selected after the preliminary test on rats in temporary hyperglycemia because it proved to be the most active. The results presented in Figure 2 show the evolution of blood glucose throughout the test. Three days after the injection of alloxan, frequent urination, hunger, weight loss, fatigue, and a significant increase in blood glucose were observed. During the first 5 days of treatment, blood glucose remains constant. Then, in the case of negative control rats, an increase in blood glucose is observed whereas this decreases in the treated rats. This decrease in blood glucose is very marked in positive control rats treated with glibenclamide at a dose of $2.5 \mathrm{mg} / \mathrm{kg}$ of body weight. The decrease in blood glucose in the rats treated with the dose of $150 \mathrm{mg} / \mathrm{kg}$ of body weight is greater compared to the decrease caused by the two other doses. The glycemia of the neutral control rats remains more or less constant over the course of the experimentation time. 


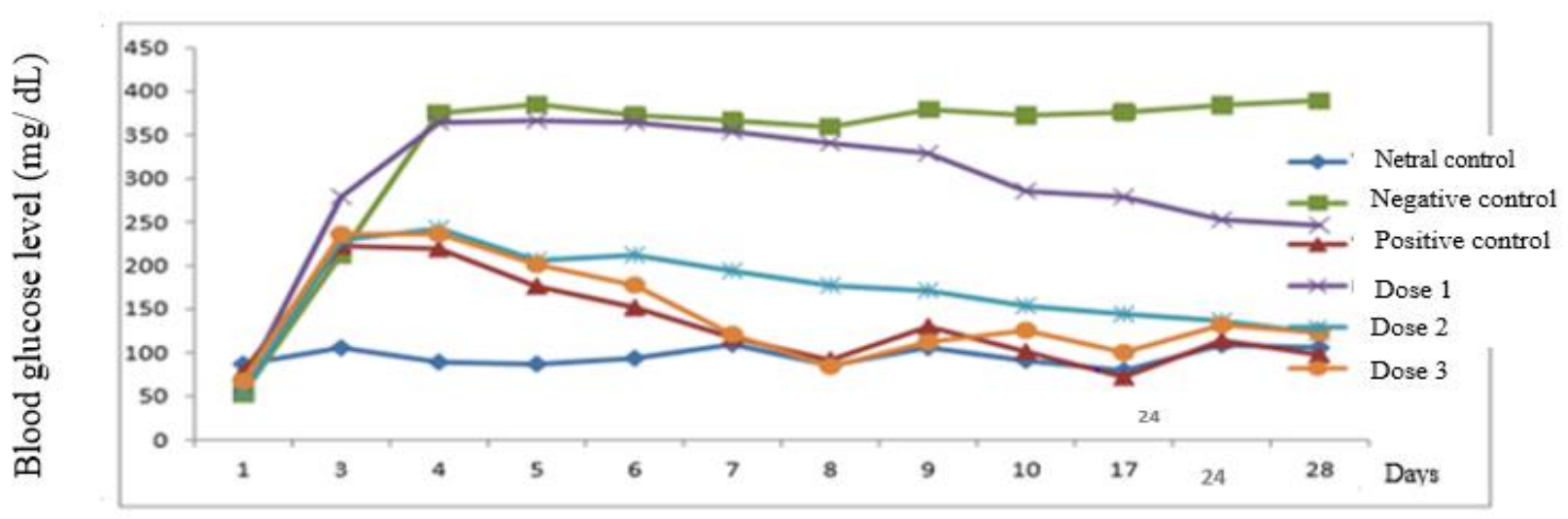

Figure 2: Curve showing the evolution of blood glucose levels during treatment of diabetic rats

\subsubsection{Effects of The Plant on The Relative Weight of Organs}

The values of the relative weights of some organs (heart, liver, kidneys, pancreas) of the rats of the different batches are presented in table 3. This table shows that there are no significant differences between the relative weight values of the heart, liver and kidneys of animals from different groups $(\mathrm{P}>0.5)$. However, there was a reduction in the relative weight of the pancreas of negative and positive $(\mathrm{P}<0.5)$ controls.

Table 3: Relative Organ Weights of Rats (\%)

\begin{tabular}{|l|c|c|c|c|c|c|}
\hline \multirow{2}{*}{ Organs } & \multicolumn{7}{|c|}{ Groups } \\
\cline { 2 - 7 } & $\begin{array}{c}\text { Healthy } \\
\text { control }\end{array}$ & $\begin{array}{c}\text { Negative } \\
\text { control }\end{array}$ & $\begin{array}{c}\text { Positive } \\
\text { control }\end{array}$ & D1 & D2 & D3 \\
\hline Heart & $0.33 \pm 0.03^{\mathrm{a}}$ & $0.32 \pm 0.02^{\mathrm{a}}$ & $0.32 \pm 0.02^{\mathrm{a}}$ & $0.33 \pm 0.02^{\mathrm{a}}$ & $0.31 \pm 0.02^{\mathrm{a}}$ & $0.34 \pm 0.031^{\mathrm{a}}$ \\
\hline Liver & $3.44 \pm 0.20^{\mathrm{a}}$ & $3.83 \pm 0.35^{\mathrm{a}}$ & $3.07 \pm 0.40^{\mathrm{a}}$ & $3.86 \pm 0.20^{\mathrm{a}}$ & $3.61 \pm 0.43^{\mathrm{a}}$ & $3.49 \pm 0.31^{\mathrm{a}}$ \\
\hline Kidney & $0.72 \pm 0.09^{\mathrm{a}}$ & $0.74 \pm 0.06^{\mathrm{a}}$ & $0.74 \pm 0.06^{\mathrm{a}}$ & $0.73 \pm 0.03^{\mathrm{a}}$ & $0.88 \pm 0.07^{\mathrm{a}}$ & $0.86 \pm 0.06^{\mathrm{a}}$ \\
\hline Pancreas & $0.57 \pm 0.02^{\mathrm{a}}$ & $0.36 \pm 0.08^{\mathrm{b}}$ & $0.38 \pm 0.01^{\mathrm{b}}$ & $0.62 \pm 0.03^{\mathrm{a}}$ & $0.59 \pm 0.026^{\mathrm{a}}$ & $0.60 \pm 0.002^{\mathrm{a}}$ \\
\hline
\end{tabular}

The values of the relative weight of organs on the same line and affected by the same superscript letter are not statistically significant at the $5 \%$ level. $\mathrm{N}=3$ repetitions

\subsubsection{Effect of The Plant on Hematological Parameters}

The results obtained after measuring the hematological parameters are shown in Table 4. The leucocyte count values of the different groups of rats showed a significant drop in WBC levels of negative control rats.

The administration of the methanol extract of P. americana at D2 and D3 doses and glibenclamide increased the WBC level to a level comparable to that of the healthy control. The same observations were made on the level of granulocytes. Also, the RBC, HCT and HGB and MCV levels representing the erythrocyte numbering decrease slightly in negative control rats. However, these levels increase in rats treated with glibenclamides and plant extracts at the dose D2 and D3. The extract at doses D2 and D3 corrects the change in RBC level better than the dose D1. There was also a decrease in platelet count in negative control rats and a significant increase in platelets in treated rats. 
Table 4: Hematological parameters of animals

\begin{tabular}{|l|c|c|c|c|c|c|}
\hline Parameters & $\begin{array}{c}\text { Healthy } \\
\text { control }\end{array}$ & $\begin{array}{c}\text { Negative } \\
\text { control }\end{array}$ & $\begin{array}{c}\text { Positive } \\
\text { control }\end{array}$ & D1 & D2 & D3 \\
\hline WBC & $7.13 \pm 4.33^{\mathrm{a}}$ & $5.50 \pm 4.30^{\mathrm{a}}$ & $6.06 \pm 3.30^{\mathrm{a}}$ & $5.20 \pm 2.11^{\mathrm{a}}$ & $6.36 \pm 2.54^{\mathrm{a}}$ & $7,10 \pm 1,20^{\mathrm{a}}$ \\
\hline LYM\% & $83.93 \pm 4.80^{\mathrm{b}}$ & $83.20 \pm 12.45^{\mathrm{b}}$ & $87.733 \pm 6.95^{\mathrm{b}}$ & $84.83 \pm 2.57^{\mathrm{b}}$ & $75.13 \pm 9.82^{\mathrm{a}}$ & $77,40 \pm 11,98^{\mathrm{a}}$ \\
\hline MON\% & $3.966 \pm 1.625^{\mathrm{a}}$ & $3.80 \pm 1.34^{\mathrm{a}}$ & $3,600 \pm 1.24^{\mathrm{a}}$ & $4.23 \pm 1.45^{\mathrm{a}}$ & $6.566 \pm 4.158^{\mathrm{a}}$ & $5,00 \pm 1,57^{\mathrm{a}}$ \\
\hline GRAN\% & $12.10 \pm 3.96^{\mathrm{a}}$ & $7.00 \pm 11.97^{\mathrm{a}}$ & $866 \pm 5.87^{\mathrm{a}}$ & $10.93 \pm 2.51^{\mathrm{a}}$ & $17.30 \pm 5.67^{\mathrm{a}}$ & $18,60 \pm 10,42^{\mathrm{a}}$ \\
\hline RBC & $7.23 \pm 0.99^{\mathrm{a}}$ & $6.83 \pm 0.37^{\mathrm{a}}$ & $6.76 \pm 1.26^{\mathrm{a}}$ & $6.80 \pm 0.43^{\mathrm{a}}$ & $5.23 \pm 2.66^{\mathrm{a}}$ & $6,60 \pm 0,31^{\mathrm{a}}$ \\
\hline HGB & $15.23 \pm 1.75^{\mathrm{a}}$ & $14.23 \pm 0.47^{\mathrm{a}}$ & $15.13 \pm 2.55^{\mathrm{a}}$ & $14.26 \pm 0.55^{\mathrm{a}}$ & $14.40 \pm 2.17^{\mathrm{a}}$ & $14,98 \pm 1,11^{\mathrm{a}}$ \\
\hline HCT & $35.13 \pm 5.37^{\mathrm{a}}$ & $32.23 \pm 1.87^{\mathrm{a}}$ & $36.40 \pm 12.04^{\mathrm{a}}$ & $31.30 \pm 2.10^{\mathrm{a}}$ & $29.33 \pm 8.19^{\mathrm{a}}$ & $31,00 \pm 2,34^{\mathrm{a}}$ \\
\hline ACV & $58.56 \pm 0.92^{\mathrm{a}}$ & $47.23 \pm 0.83^{\mathrm{a}}$ & $52.30 \pm 6.12^{\mathrm{a}}$ & $46.06 \pm 1.00^{\mathrm{a}}$ & $46.76 \pm 28.55^{\mathrm{a}}$ & $54,93 \pm 1,32^{\mathrm{a}}$ \\
\hline MCH & $21.06 \pm 0.50^{\mathrm{a}}$ & $20.83 \pm 0.66^{\mathrm{a}}$ & $23.86 \pm 2.35^{\mathrm{a}}$ & $20.93 \pm 0.47^{\mathrm{a}}$ & $25.90 \pm 20.43^{\mathrm{a}}$ & $31,53 \pm 0,75^{\mathrm{a}}$ \\
\hline ACCH & $43.46 \pm 1.66^{\mathrm{a}}$ & $44.20 \pm 1.96^{\mathrm{a}}$ & $45.93 \pm 4.72^{\mathrm{a}}$ & $45.60 \pm 1.58^{\mathrm{a}}$ & $50.30 \pm 7.83^{\mathrm{a}}$ & $45,96 \pm 0,80^{\mathrm{a}}$ \\
\hline PLT & $32.33 \pm 90.35^{\mathrm{a}}$ & $316.66 \pm 105.19^{\mathrm{a}}$ & $369.33 \pm 89.51^{\mathrm{a}}$ & $255.00 \pm 141.17^{\mathrm{a}}$ & $506.33 \pm 191.50^{\mathrm{b}}$ & $446,66 \pm 38,01^{\mathrm{b}}$ \\
\hline MPV & $8.50 \pm 1.83^{\mathrm{a}}$ & $8.06 \pm 0.72^{\mathrm{a}}$ & $8.46 \pm 0.66^{\mathrm{a}}$ & $10.26 \pm 2.46^{\mathrm{a}}$ & $8.93 \pm 0.96^{\mathrm{a}}$ & $8,66 \pm 0,77^{\mathrm{a}}$ \\
\hline PCT & $0.26 \pm 0.04^{\mathrm{a}}$ & $0.26 \pm 0.11^{\mathrm{a}}$ & $0.31 \pm 0.10^{\mathrm{a}}$ & $0.23 \pm 0.09^{\mathrm{a}}$ & $0.44 \pm 0.14^{\mathrm{a}}$ & $0,38 \pm 0,07^{\mathrm{a}}$ \\
\hline
\end{tabular}

$\mathrm{WBC}=$ White Blood Cell, LYM= Lymphocytes, HGB = Hemoglobin, HCT = Hematocrite, ACV =Average Corpuscular Volume, ACCH = Average Corpuscular Concentration in Hemoglobin, MON= Monocyte, GRAN = Granulocytes RBC: Red Blood Cell, PLT = Platelets, APV = Average Platelet Volume

\subsubsection{Effect of The Plant on Biochemical Parameters}

The effect of the methanolic extract of $P$. americana on the biochemical parameters shown in Table 5 indicates a significant increase in cholesterol levels in the negative controls. The administration of the extract led to a decrease in the cholesterol and LDL levels in a dose reponse manner. The same observation was made for serum HDL levels. There wasis a significant increase in urea and creatinine in negative controls. The ALT and ASAT levels did not show significant variations between the different batches.

Table 5: Effect of methanolic extract of P. americana on serum biochemical parameters

\begin{tabular}{|l|c|c|c|c|c|c|}
\hline Groups & $\begin{array}{c}\text { Healthy } \\
\text { control }\end{array}$ & $\begin{array}{c}\text { Negative } \\
\text { control }\end{array}$ & $\begin{array}{c}\text { Positive } \\
\text { control }\end{array}$ & D1 & D2 & D 3 \\
\hline Cholesterol & $127.07 \pm 11.2^{\mathrm{a}}$ & $245.93 \pm 5.93^{\mathrm{c}}$ & $127.61 \pm 2.41^{\mathrm{a}}$ & $205.56 \pm 3.83^{\mathrm{c}}$ & $151.13 \pm 7.14^{\mathrm{b}}$ & $138.17 \pm 4.19^{\mathrm{b}}$ \\
\hline $\begin{array}{l}\text { Totale } \\
\text { protein }\end{array}$ & $4.40 \pm 0.71^{\mathrm{a}}$ & $5.98 \pm 0.64^{\mathrm{b}}$ & $5.25 \pm 0.47^{\mathrm{ab}}$ & $5.59 \pm 0.81^{\mathrm{ab}}$ & $5.00 \pm 1.03^{\mathrm{a}}$ & $4.71 \pm 0.58^{\mathrm{a}}$ \\
\hline ALAT & $77.46 \pm 3.57^{\mathrm{a}}$ & $185.25 \pm 10.37 \mathrm{c}$ & $104.27 \pm 4.61^{\mathrm{ab}}$ & $156.42 \pm 9.40^{\mathrm{c}}$ & $126.85 \pm 3.18^{\mathrm{b}}$ & $83.72 \pm 7.51^{\mathrm{a}}$ \\
\hline ASAT & $118.24 \pm 7.77^{\mathrm{a}}$ & $204.49 \pm 4.93^{\mathrm{c}}$ & $120.26 \pm 8.99^{\mathrm{a}}$ & $155.12 \pm 1.40^{\mathrm{b}}$ & $119.60 \pm 7.92^{\mathrm{ab}}$ & $108.57 \pm 6.66^{\mathrm{a}}$ \\
\hline TG & $54.18 \pm 5.60^{\mathrm{a}}$ & $163.33 \pm 12.33^{\mathrm{c}}$ & $82.60 \pm 3.26^{\mathrm{b}}$ & $135.46 \pm 5.97^{\mathrm{c}}$ & $96.73 \pm 4.56^{\mathrm{b}}$ & $83.59 \pm 5.94^{\mathrm{b}}$ \\
\hline HDL & $54.86 \pm 4.07^{\mathrm{b}}$ & $45.19 \pm 1.15^{\mathrm{a}}$ & $63.66 \pm 1.26^{\mathrm{c}}$ & $64.15 \pm 3.46^{\mathrm{c}}$ & $69.12 \pm 3.91^{\mathrm{c}}$ & $74.13 \pm 4.79^{\mathrm{d}}$ \\
\hline Créatinine & $8.00 \pm 2.00^{\mathrm{ab}}$ & $19.40 \pm 5.91^{\mathrm{c}}$ & $7.62 \pm 1.00^{\mathrm{b}}$ & $13.14 \pm 5.48^{\mathrm{c}}$ & $10.33 \pm 2.36^{\mathrm{b}}$ & $7.51 \pm 3.92^{\mathrm{b}}$ \\
\hline Urée & $80.00 \pm 2.19^{\mathrm{a}}$ & $110.28 \pm 2.91^{\mathrm{b}}$ & $74.47 \pm 7.86^{\mathrm{a}}$ & $106.66 \pm 1.44^{\mathrm{b}}$ & $98.57 \pm 5.46^{\mathrm{a}}$ & $76.66 \pm 2.31^{\mathrm{a}}$ \\
\hline LDL & $3.60 \pm 0.86^{\mathrm{b}}$ & $6.28 \pm 1.82^{\mathrm{c}}$ & $0.26 \pm 0.028^{\mathrm{a}}$ & $1.18 \pm 0.14^{\mathrm{a}}$ & $0.685 \pm 0.24^{\mathrm{a}}$ & $0.25 \pm 0.04^{\mathrm{a}}$ \\
\hline
\end{tabular}

Values on the same line with the same superscript letter are not statistically significant at the $5 \%$ level. $\mathrm{N}=3 \mathrm{repetitions}$

\subsubsection{Antidiabetic Mechanism of Action of Extracts}

To verify their mechanisms of action, extracts were tested against alpha glucosidase, beta glucosidase and glucoamylase. Table 6 presents the inhibitory potential of the extracts on $\alpha$ glucosidase, $\beta$-glucosidase and glucoamylase. It can be seen from this table that with the exception of the aqueous and methanol extracts of Catharanthus roseus, the others showed strong inhibitory 
properties against alpha glucosidase and glucoamylase enzymes with inhibition percentages greater than $90 \%$. This was confirmed with $\mathrm{IC}_{50}$ values. In fact, From Table 6 , it can be noted that except $C$. roseus extract, the other tested extracts were highly potent inhibitors of $\alpha$-glucosidase and glucoamylase $\left(1.26 \pm 0.03 \leq \mathrm{IC}_{50} \leq 9.37 \pm 0.91\right)$. Among these extracts, $P$. americana methanol extract appeared to be the most active $\left(\mathrm{IC}_{50}=1.26 \pm 0.03\right)$ compared with $\mathrm{IC}_{50}$ values of $P$. americana aqueous extract and $E$. globulus extracts. To check the selectivity of these extracts, they were also tested against $\beta$-glucosidase. The tested extracts showed less than $17 \%$ inhibition when tested at $0.1 \mathrm{mg} / \mathrm{mL}$ end concentration, meaning that they did not almost inhibit $\beta$-glucosidase (Table 6). However, both $P$. americana and E. globulus extracts were significantly $(\mathrm{P}<0.05)$ more active against $\alpha$-glucosidase and glucoamylase when compared to the tested positive control.

Table 6: Inhibitory potential of extracts on $\alpha$-glucosidase, $\beta$-glucosidase and glucoamylase

\begin{tabular}{|c|c|c|c|c|c|c|}
\hline & \multirow[t]{2}{*}{ Extracts } & \multicolumn{2}{|c|}{$\alpha$-glucosidase } & \multirow{2}{*}{ 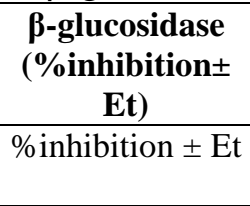 } & \multicolumn{2}{|c|}{ Glucoamylase } \\
\hline & & $\begin{array}{c}\text { \%inhibition } \\
\pm \mathrm{Et}\end{array}$ & $\begin{array}{c}\mathrm{IC}_{50} \text { in } \\
\mu \mathrm{g} / \mathrm{ml} \pm \mathrm{Et}\end{array}$ & & $\begin{array}{c}\text { \%inhibition } \\
\pm \mathrm{Et}\end{array}$ & $\begin{array}{c}\mathrm{IC}_{50} \text { in } \\
\mu \mathrm{g} / \mathrm{ml} \pm \mathrm{Et}\end{array}$ \\
\hline P. americana & $\begin{array}{l}\text { Methanolic } \\
\text { extract }\end{array}$ & $98.38 \pm 0.42$ & $\begin{array}{c}7.51 \pm 0.20^{\mathrm{a}} \\
{[8]}\end{array}$ & $15.63 \pm 1.23[8]$ & $98.99 \pm 2.05$ & $\begin{array}{c}1.26 \pm 0.03^{\mathrm{a}} \\
{[8]}\end{array}$ \\
\hline C. roseus & $\begin{array}{l}\text { Aqueous } \\
\text { extract }\end{array}$ & $92.96 \pm 1.39$ & $30.6 \pm 0.40^{b}$ & $15.93 \pm 0.27$ & $91.74 \pm 1.82$ & $34.02 \pm 2.01^{\mathrm{c}}$ \\
\hline \multirow{2}{*}{$\begin{array}{l}\text { C. roseus } \\
\text { E. globulus }\end{array}$} & $\begin{array}{l}\text { Methanolic } \\
\text { extract }\end{array}$ & $8.31 \pm 1.77$ & I & $16.90 \pm 0.58$ & $42.33 \pm 3.44$ & I \\
\hline & $\begin{array}{l}\text { Aqueous } \\
\text { extract }\end{array}$ & $3.48 \pm 0.51$ & I & $14.66 \pm 0.60$ & $47.13 \pm 9.84$ & I \\
\hline \multirow{2}{*}{$\begin{array}{l}\text { E. globulus } \\
\text { Acarbose }\end{array}$} & $\begin{array}{l}\text { Methanolic } \\
\text { extract }\end{array}$ & $98.36 \pm 0.42$ & $7.62 \pm 0.88^{a}$ & $10.15 \pm 1.33$ & $96.66 \pm 1.91$ & $7.86 \pm 0.71^{b}$ \\
\hline & $\begin{array}{l}\text { Aqueous } \\
\text { extract }\end{array}$ & $96.22 \pm 0.70$ & $8.12 \pm 0.48^{a}$ & $10.89 \pm 1.10$ & $94.93 \pm 0.56$ & $9.37 \pm 0.91^{b}$ \\
\hline \multirow[t]{2}{*}{ Castanospermine } & I & $72.77 \pm 0.26$ & $\begin{array}{c}343.60 \pm \\
4.90^{\mathrm{c}} \\
\end{array}$ & I & $70.67 \pm 0.42$ & $\begin{array}{c}443.50 \pm \\
3.40^{\mathrm{d}} \\
\end{array}$ \\
\hline & I & $48.04 \pm 0.29$ & / & $59.98 \%$ & $46.99 \pm 0.08$ & I \\
\hline
\end{tabular}

Values with the different letter superscripts along each column, are considerably different.

\section{Discussion}

\subsection{Antidiabetic Activity of Extracts}

The decrease in blood glucose levels in rats with temporary hyperglycemia may be due to the presence of hypoglycemic agents in plant extracts that act either by stimulating the release of insulin by $\beta$-cells of islets of Langerhans, or by inhibiting certain enzymes that catalyze blood glucose formation [13]. The effect would be similar to that of glibenclamide, which induces the exocytosis of insulin in $\beta$-cells [14], thus causing an increase in plasma insulin concentration, resulting in an insulin-modulating effect on peripheral tissues (liver and skeletal muscle) and thus a rapid drop in hyperglycemia in rats [15]. However, maximal activity was noted for the methanolic extract of $P$. americana which caused a significant decrease in glucose after 120 minutes. 
Phytochemical screening of the extracts showed the presence of numerous secondary metabolites such as flavonoids, alkaloids, tannins, phenols and anthocyanins in plant extracts. These could be at the origin of the observed antidiabetic activity. Indeed, several studies have already had to show that these secondary metabolites are endowed with antidiabetic activity [16]. Flavonoids are endowed with hypoglycemic and antidiabetic properties [17] and act by inhibiting alkalose reductase or protecting organs against toxicity or oxidative stress due to agents such as alloxan. [18]. Alkaloids are nitrogenous substances produced by the plant and whose hypoglycemic applications have been proven [19]. Triterpenes are considered potentially promising molecules for the development of new antidiabetic drugs [20]. They are also considered as a class of hypoglycemic molecules that may act in part by inhibiting glycogen phosphorylase, a key enzyme in glycogen hydrolysis [21]. Saponins possess hypoglycemic activity, which may be due to inhibition of liver glycogen hydrolysis [22], and may contribute to the observation of the hypoglycemic activity of the plant extract. Flavonoids, tannins and saponins have also been reported by Tiwari and Rao [23] to possess hypoglycemic properties via an inhibitory action on the sodium glucose transporter 1 (S-GLUT1). Moreover, Njateng et al. [8] identified alkanes, esters and compounds with benzene ring in the emthanol extract of $P$. americana and suggested that they may possess antidiabetic properties.

The decrease in pancreatic volume in untreated diabetic rats is due to the destruction of $\beta$ cells. Comparative studies have shown that diabetes is accompanied by a reduction in the mass of pancreatic $\beta$ cells. Indeed, these results corroborate those obtained by N'guessan et al. [24] who studied the effect of the aqueous extract of $P$. americana on diabetic rats. The increase in the pancreas mass in the rats treated with the methanolic extracts of $P$. americana may be due to the presence in this extract of hypoglycemic molecules capable of regenerating the $\beta$ cells, and to potentiate the secretion of insulin by the $\beta$ cells of islets of Langerhans. Indeed, Ezejiofor et al. [7] showed that hot aqueous $P$. americana seeds extracts had antidiabetic and protective effects on some rat tissues as the pancreas, kidneys and liver as it could reverse the histopathological damage that occurred in alloxan-induced diabetic rats with regenerative effects on $\beta$ cells, and is capable of stimulating insulin production. Higher concentrations of the extract may have exhibited a greater restorative effect on islet cells of diabetic rats than lower dose extracts.

\subsection{Effect of Methanol Extract of P. Americana on Hematological Parameters}

A slight decrease in lymphocyte and granulocyte levels observed in untreated diabetic rats causing leukopenia is thought to be due to depression of the immune system, a sign of disruption of bone marrow activity in these animals. The fall of the granulocyte population is due to their death at the end of their intense phagocytic activity. Indeed, the latter would have participated in the elimination of $\beta$ cells died by necrosis following the administration of alloxan. Treatment of the rats with glibenclamide as well as with the extract corrects leukopenia by increasing the level of lymphocytes and granulocytes. These treatments show that the metabolites of the extract have an immunomodulatory effect and thus protect the bone marrow from the toxicity of alloxan. The onset of diabetes in rats would cause a decrease in the rate of erythrocytes leading to anemia [25]. Indeed, polyuria resulting from the diabetic state causes a decrease in blood volume and therefore dehydration [25]. Administration of glibenclamide to positive control rats as well as the methanolic extract of $P$. americana at doses 75 and $150 \mathrm{mg} / \mathrm{kg}$ body weight increased erythrocyte levels and thus prevented the establishment of this anemia in treated rats. 


\subsection{Effect of Methanol Extract of P. Americana on Biochemical Parameters}

The increase in serum cholesterol and triglyceride levels observed in negative control rats compared to healthy control rats may be due to the absence of insulin caused by the destruction of pancreatic $\beta$ cells following the injection of alloxan. Indeed, Betterridge et al. [26] reported that insulin deficiency or insulin resistance may be responsible for hyperlipidemia, since insulin has an inhibitory action on 3-hydroxy-3-methyl-glutaryl coenzyme A reductase (HMG-COA reductase), a key enzyme in the biosynthesis of cholesterol. A significant decrease in cholesterol and triglyceride levels was observed in rrats teated with glibenclamide and methanol extracts of $P$. americana at doses of 75 and $150 \mathrm{mg} / \mathrm{kg}$ body weight. Some previous works have also shown similar results and suggested that the high abnormal serum lipid concentration observed in diabetic subjects may be mainly due to the increased mobilization of fatty acids from adipose tissue, a consequence of the action of lipolytic hormones [27, 28, 29, 30]. Several articles have shown that the administration of aqueous extracts of $P$. Americana in hypercholesteremic rats causes a decrease in blood glucose and cholesterol levels [31]. The increase in serum urea and serum creatinine observed in untreated diabetic rats is related to renal dysfunction in diabetic rats, resulting from the nephrotoxicity of alloxan [25]. Treatment of the rats with glibenclamide as well as with the extract would cause a decrease in uremia and creatinine. These treatments would thus protect the kidneys from the toxicity of alloxan.

The ALT, ASAT and total protein levels were comparable in all the groups, There was therefore no hepatic toxicity of the alloxan or plant, or the treatments would preserve the liver of the low toxicity of alloxan observed in diabetic controls, which corroborates the work done by boubouche [25] who showed that hepatic lesions depend on the quantity and route of injection of alloxan and according to Du-Bois [32], the intracardiac route would be more incriminated in hepatotoxicity than the intraperitoneal route.

\subsection{Mechanism of Action of Extracts}

The methanol and aqueous extracts of $P$. americana, $C$. roseus, and E. globulus act by exerting inhibitory effects against $\alpha$-glucosidase and glucoamylase enzymes. This inhibitory potential is thought to be due to the presence of flavonoids, alkaloids and phenolic compounds in their chemical composition. Indeed, studies have shown that monomeric flavonoids inhibit the activity of $\alpha$-amylase and $\alpha$-glucosidase [33, 34]. These results corroborate those of Chattopadhyays [35] who also showed that alkaloids act by inhibiting the enzyme $\alpha$-glucosidase and cause the decrease of glucose transport across the intestinal barrier. The overall effect of inhibition would be to reduce glucose flux from complex dietary carbohydrates into the bloodstream, which would decrease the postprandial effect of starch consumption on blood glucose levels. Gas chromatography of the methanolic extract of $P$. americana showed the presence of several phenolic compounds. Those compounds could be at the origin of the antidiabetic activity of this extract. Indeed, several studies have also shown that the polyphenolic fractions of plants inhibit the activity of $\alpha$-amylase and $\alpha$ glucosidase and allow a tighter control of blood glucose $[8,36]$. 


\section{Conclusion}

This investigation, shows that the tested plant extract possess a strong hypoglycemic activity, the best activity being presented by the methanol extract from leaves of $P$. americana. These extracts act by inhibiting alpha glucosidase and glucoamylase. The data suggest that they are potential antidiabetic extracts that can lead to the discovery of novel potential drugs for diabetes with dual action. To this end, we intend to search for the antidiabetic compounds that could justify these activities.

\section{Declarations}

\section{Ethics Approval}

All studies involving animals were conducted according to the ethical guidelines of the Committee for Control and Supervision of Experiments on Animals (Registration no. 173/CPCSEA, dated 28 January, 2000), Government of India, on the use of animals for scientific research.

\section{List of Abbreviations}

Not applicable

\section{Consent for publication}

Not applicable

\section{Availability of data and material}

Not applicable

\section{Competing Interests}

The authors declare that they have no competing interests.

\section{Funding}

This study was supported by the CIIT-TWAS (Third World Academy of Science -Comsats Institute of Information Technology) grant to the second author (Awardee of the CIIT-TWAS Postdoctoral Fellowship FR number: 3240293205) as well as the University of Dschang and the Ministry of Higher Education through allowances to university Teachers for research. CIIT-TWAS provided chemicals and equipment needed to handle the mechanism of action of the tested extracts as well as all the necessaries for the design of the study, collection, analysis, interpretation of data and writing of the manuscript. The design of the in vivo study, collection, analysis, and interpretation of data were financed by the University of Dschang and the Cameroon Ministry of Higher Education.

\section{Authors' Contributions}

LYC is the main field investigator. GSSN designed the study and determined mechanism of action of extracts. JI supervised the study of the mechanism of action of extracts. AJAD and CF contributed to the field work. SLT and RSM contributed to drafting the manuscript. All authors read and approved the final manuscript. 


\section{Acknowledgments}

We acknowledge the financial and technical supports of TWAS (Third World Academy of Science) and CIIT (Comsats Institute of Information Technology) as well as the financial supports of the University of Dschang and the Cameroonian Ministry of Higher Education.

\section{Author's Information}

1 Laboratory of Microbiology and Antimicrobial Substances, Faculty of Science, University of Dschang, P.O. Box 67 Dschang, Cameroon. 2 Center for Advance Drug Research, COMSATS Institute of Information Technology, Abbottabad-22060, Pakistan; 3 Institute of Fisheries and Aquatic Sciences, University of Douala, Cameroon, P.O Box 7236, Douala, Cameroon.

\section{References}

[1] Thaane T, Motala AA, McKune AJ. Effects of Short-Term Exercise in Overweight/Obese Adults with Insulin Resistance or Type 2 Diabetes: A Systematic Review of Randomized Controlled Trials. J Diabetes Metab. 2018; 9:12.

[2] International Diabetes federation (IDF). Diabetes Atlas, 6th edition, 2014, 160p.

[3] Kirkman MS. Dual oral agent therapy for type 2 diabetes: Why don't our patients stick with it? J Diabetes Complicat 2016; 30:1417-1418.

[4] Feudjio C, Njateng GSS, Kuiate J-K. Evaluation of Antidiabetic Activity of Aqueous Extract of Leaves from Phragmanthera capitata (Sprengel) S. Balle (Laurenthaceae) in Wistar Albino Rats. J Diseases Med Plants. 2018; 4:96-109.

[5] Al-Shaqha WM, Khan M, Salam N, Azzi A, Chaudhary AA. Anti-diabetic potential of Catharanthus roseus Linn. and its effect on the glucose transport gene (GLUT-2 and GLUT-4) in streptozotocin induced diabetic wistar rats. BMC Complement Altern Med. 2015; 15:379

[6] Houacine C, Elkhawad AO, Ayoub SMH. A comparative study on the anti-diabetic activity of extracts of some Algerian and Sudanese plants. J Diabetes Endocrinol. 2012; 3:25-28.

[7] Ezejiofor AN, Okorie A, Orisakwe OE. Hypoglycaemic and Tissue-Protective Effects of the Aqueous Extract of Persea Americana Seeds on Alloxan-Induced Albino Rats. Malays J Med Sci. 2013; 20:31-39.

[8] Njateng GSS, Zaib S, Chimi YL, Feudjio C, Mouokeu RS, Gatsing D et al. Antidiabetic potential of methanol extracts from leaves of Piper umbellatum L. and Persea americana Mill. Asian Pacific J Trop Biomed. 2018; 8:160-165.

[9] Bruneton J. Pharmacognosie, Phytochimie, Plantes médicinales. 3ième Edition. Paris: Lavoisier; 1999.

[10] Szkudelski T. The Mechanism of Alloxan and Streptozotocin Action in B Cells of the Rat Pancreas. Physiol Res. 2001; 50:536-546

[11] Njateng GSS, Gatsing D, Mouokeu RS, Kuiate J-R. Dermal Toxicity Study of an Antidermatophytic Oil-moistened Dichloromethane-Methanol (1:1 v/v) Stem Bark Extract of Polyscias fulva Hiern (Araliaceae) in Guinea Pigs Animal Model. Intern J Pharm. 2014; 4:53-60.

[12] Ma H, Gaoh H, Sun L, Huang J., Xu X. Wu L. constituent with alpha glucosidase and advanced glycathion end- product formation inhibitory activities from salvia miltorrhiza bge. $\mathrm{J}$ nat Med. 2011; 65:37-42

[13] Doyle E, Egan M. Pharmacological Agents That Directly Modulate Insulin Secretion. Pharmacol reviews. 2003; 55:105-131.

[14] Tian Y, Johnson G, Ashcroft S. Sulfonylureas enhance exocytosis from pancreatic beta-cells by a mechanism that does not involve direct activation of protein kinase C. Diabetes. 1998; 47:17221726. 
[15] Essam A, Elberry A, Harraz F, Ghareib A, Nagy A, Gabr A. Antihyperglycemic and hypolipidaemic effects of the methanolic extract of Saudi mistletoe (Viscum schimperi Engl.), J Advanced Res. 2011;2:171-177.

[16] Guerci B, Bohme P, Kearney-Schwartz A, Zannad F, Drouin P. Endothelial dysfunction and type 2 diabetes. Diabetes Metab. 2001; 27:436-447.

[17] Kim S, Hyun S, Choung S. Anti-diabetic effect of cinnamon extract on blood glucose in db/db mice. J Ethnopharmacol. 2006; 104:119-123.

[18] Lukačínová A, Mojžiš R, Beňačka J, Keller T, Maguth P, Kurila L et al. Preventive Effects of Flavonoids on Alloxan-Induced Diabetes Mellitus in Rats. Acta Vet Brno. 2008; 77:175-82.

[19] Silvestrini A, Pasqua G, Botta B, Monacelli B, Heijden R, Vonder Verpoorte R. Effects of alkaloid precursor feeding on a camptotheca acumisate cell line. Plant Physiol Biochem. 2002; 40:749-753.

[20] Li W, Zheng H, Bukuru J, DeKimpe N. Natural medicines used in the traditional Chinese medical system for therapy of diabetes mellitus. J Ethnopharmacol. 2004; 92:1-21.

[21] Wen X, Sun H, Liu J, Cheng K, Zhang P, Zhang L, et al. Naturally occurring pentacyclic triterpenes as inhibitors of glycogen phosphorylase: synthesis, structure- activity relationships, and X-ray crystallographic studies $\dagger$. J med chem. 2008;51;3540-3554.

[22] Nakashima N, Kimura I, Kimura M, Matsura H. Isolation of pseudoprototimosaponin AIII from rhizomes of anemarrhenaasphodeloides and its hypoglycemic activity in steptozotocin-induced diabetic mice. J Nat Prod. 1993; 56:345-350

[23] Tiwar A, Rao J. Diabetic mellitus and multiple therapeutic approaches of phytochemicals: Present status and future prospects. Curr Sci. 2002; 83:30-37.

[24] N'guessan K, Amoikon K, Soro D. Effect of Aqueous Extract of Persea Americana Seeds on the Glycemia of Diabetic Rabbits. Eur j Sci Res. 2009; 26:376-385.

[25] Bouhouche I. Etude comparative de l'alloxane et de la streptozocine dans le diabète expérimental chez le rat blanc. Etude histologique du pancréas endocrine et la variation des paramètres sanguins. Mémoire de Magister en Biologie Animale, Université Constantine 1, Algérie, 2015;109 p.

[26] Betterridge J. Lipid disorders in diabetes mellitus In Pickup J and Williams G. textbook of diabetes. London: Blackwell Science; 2002.

[27] Eddouks M, Lemhadri A, Michel JB. Hypolipidemic activity of aqueous extract of Capparis spinosa L. in normal and diabetic rats. J Ethnopharmacol. 2005; 98:345-350.

[28] Ravi Ram K, Ji S, Wolfner MF. Fates and targets of male accessory gland proteins in mated female Drosophila melanogaster. Insect Biochem Mol Biol. 2005; 35:1059-1071.

[29] Nkanu EE, Eno AE, Ofem OE, Imoru JO, Unoh FB. Effect of crude extract of Viscum album (mistletoe) on plasma lipids: an insight into its possible antihyperglycaemic and antihypertensive properties. Port Harcourt Med J. 2007; 1:171-177

[30] Sharma B, Viswanath G, Salunke R, Roy P. Effects of flavonoid-rich extract from seeds of Eugenia jambolana (L.) on carbohydrate and lipid metabolism in diabetic mice. Food Chem. 2008; 110:697705.

[31] Bra B, Odetola A, Agomo P. Hypoglycemic and hypocholesterolemic potential of Persea americana leaf extracts, J Med Food. 2007; 10:356-360.

[32] Du-Bois A. Action de l'intoxication alloxanique sur le foie de cobaye. Cellule and tissu research. $1954 ; 40: 585-604$

[33] Gamberucci A, Konta L, Colucci A, Giunti R, Magyar J, Mandl J, et al. Green tea flavonols inhibit glucosidase II. Biochem Pharmacol. 2006; 72:640-646.

[34] Lopiparo E, Scheib H, Frei N, Williamson G, Grigorov M, Chou C. Flavonoids for controlling starch digestion: structural requirements for inhibiting human alpha-amylase. J Med Chem. 2008; 51:3555-3561.

[35] Chattopadhyay RR. A comparative evaluation of some blood sugar lowering agents of plant origin. J Ethnopharmacol. 1999; 67:367-372. 
[36] McDougall G, Shpiro F, Dobso P, Smith P, Blake A, Stewart D. Different polyphenolic components of soft fruits inhibit alpha-amylase and alpha-glucosidase. J Agric Food Chem. 2005; 3:2760-2766.

*Corresponding author.

E-mail address: chimilarissa@ yahoo.fr/njatguysedars@ yahoo.fr/armelagokeng@ yahoo.fr/moraysi@ yahoo.fr/ cesairebio@yahoo.fr/lacmatastephen@yahoo.fr/jamshediqb@googlemail.com 